\title{
An Attitude and Character Instructional Development Based on Curriculum 2013 in Elementary School
}

\author{
Badeni Muhamad, Sri Saparahayuningsih \\ Faculty of Teacher Training and Education, Bengkulu University, Bengkulu, Indonesia \\ Email:mbmbadeni@gmail.com,badeni@unib.ac.id
}

Received 24 December 2015; accepted 18 February 2016; published 24 February 2016

Copyright (C) 2016 by authors and Scientific Research Publishing Inc.

This work is licensed under the Creative Commons Attribution International License (CC BY). http://creativecommons.org/licenses/by/4.0/

c) (i) Open Access

\begin{abstract}
The purpose of this research is to identify the weaknesses of the instructional model of attitude and character in the $\mathbf{2 0 1 3}$ elementary school curriculum and to develop a conceptual model of attitude and character instruction being able to instill the attitudes and characters contained in the content of social studies subject of elementary schools in the curriculum of 2013. The results of this study showed that 1) scientific learning approach was only able to develop scientific attitudes of students, while sorts of other attitudes were very less embedded into the students' self. 2) The application of the integrated scientific instructional model was able to instill the values of attitudes and characters contained in the content of social studies to the student.
\end{abstract}

\section{Keywords}

Criticism, Improvement, Character Instructional Model, 2013 Curriculum, Integrated Instructional Approach

\section{Introduction}

One of the various aspects of the review that lies behind the development of the curriculum in 2013 is alarming socio-cultural change. For the impact of this change, especially at this time, there was revolutionary in all aspects of life in the political, economic, social, cultural, behavioral and other dimensions of life (Wahab \& Sapriya, 2011). Examples of socio-cultural changes are marked with Indonesian culture that was once known courteous, polite, gentle, caring for others, high social, and high cooperate shifted into a nation that less social sensitivity, and selfish. There was also rampant corruption, and student brawls occur everywhere. This change also occurs in both the developed and developing countries. Reportedly, the learners of United Kingdom for in- 
stance, that the impact of science and technology causes the increase of harmful behavior, anti-social behavior, indiscipline, underachievement (Arthur, 2005: p. 250 in Robert White, 2010: p. 11), drunkenness, unsafe sex (United Nations Report, 2007 in Robert White, 2010: p. 12), and juvenile delinquency in the community. Even the most remote villages and big cities in Indonesia, the symptoms have come to a very disturbing extent, such as a fight mass, parents kill her own child, husband kills his wife and vice versa, teen fights, fighting between learners and between schools, rampant corruption, social sensitivity barren and various other cases of moral decadence. These symptoms are in accordance with Ahmad Mustafa's (criminologist Indonesia University) due to the declining value of social and community life (Koran Sindo, January 28, 2014).

In connection with this, today's society felt that the implementation of education about values, attitudes and character of the institutions of formal education was very important, and urged to increase its intensity and quality. Formal education institutions, especially primary education (including elementary schools) as an official container coaching children and young people, are expected to increase its role in shaping the character of learners through increasing the intensity and quality of education on values, attitudes and character. The government welcomed insistence by pouring the main target in the curriculum in 2013, namely the formation of attitudes and character of the young generation (Kementerian Pendidikan dan Kebudayaan, 2013). The problem is that though the educational curriculum 2013 has set the values of attitude and character, it has still become the main target in achieving the goals of education, has chosen the scientific approach as instructional model in the processes of learning and has recomended the teachers to implement it, "can the the goals be achieved through the instructional model?”

Educational experts generally agree on the importance of efforts to increase the intensity and quality of the attitude and character education in formal education. However, there are differences of opinion among them about the approach and mode of education. Associated with the approach, some experts suggest the use of moral education approaches developed in western countries, such as: the approach of cognitive moral development, value analysis approach, and values clarification approach. Others suggest the use of traditional approaches, namely through the planting of certain social values in self-learners. Attitude and character education in the school curriculum in Indonesia, the 2013 curriculum, developed a model of instruction with the scientific method approach. Is the scientific method approach able to achieve the goal of education values, attitudes and character expected? Based on the study of various theories, we doubt that that through the parctice of the scientific method it is able to achieve the goal of expected values, attitudes and character education. The appliction of scientific approach is only able to familiarize learners' scientific attitude in learning. The steps of scientific approach, namely, receiving, searching, collecting, formulating and reporting information (Kementerian Pendidikan dan Kebudayaan, 2014), have not been able to get used to the formation of attitudes as expected by the curriculum 2013. The comptence of attitudes expected is "respect and appreciate the teachings of their religion (as first core competence)", "respect and appreciate the honest behavior, discipline, responsibility, caring (tolerance, mutual aid), mannered, confident, in interacting effectively with the social and natural environment in the range interaction and existence" (as second core competence) (Kementerian Pendidikan dan Kebudayaan, 2014). The next question, what is the most appropriate approach to be done in the implementation of the attitude and character education in Indonesia? Looking at the above-mentioned problems the researchers tried to research the development of attitudes and character education approach and its implementation in the attitude and character education for students in the elementary schools.

\section{Theoretical Review}

Conceptually, attitude and character education is the direct and indirect intervention by various institutions such as the family, religious institutions, and schools that affect developments in values, attitudes and character of a person, including developments in behavior, the ability to think about whether the issues right or wrong, the actual opinion right or wrong that someone hold (Lipe, 2010). He also noted that the formal purpose of education values, attitudes and character should take into account 1) the actual act of someone that contain the situation it was right or wrong, 2) the person's ability to think critically to moral problems, and 3) the opinions of actual moral maintained by the individual (Lipe, 2010). To achieve the goal of values, attitudes and character, experts have proposed various theories about moral education. In this article approaches the value of education, attitude and character will be based on studies and typologies of educational approaches by Superka et al. (1976) in Huitt (2004). He said there are five typologies that inculcation of values education, moral development, analysis, val- 
ue clarification, and action instructional approaches.

Inculcation Approach is an approach that gives emphasis on the cultivation of social values in self-learners. Approach to education about values, attitude and character aims: 1) instill certain values in self-learners; 2) changing social values unwanted learners toward the desired value. The method used in the instructional process of this approach includes exemplary, positive and negative reinforcement, simulations, role-play, storytelling and others. A lot of experts give either support or criticism to this approach. Huitt (2004: p. 2) says, "Most educators... see values as socially or culturally accepted standards or rules of behavior.” Children actively incorporate these values into him naturally. While critics of this approach say, 1) "believe that values originate in an omnipotent Creator, 2) this approach is seen indoctrination, not in accordance with the development of democratic life (Huitt, 2004). This approach neglecting the children's right to choose their own value freely. Human life is different because of differences in time and place. We cannot predict the corresponding value for generations to come. According to the above opinion, every generation has the right to determine their value. Therefore, students need to learn instead of value, but rather the process, so they can find their own values, in accordance with the place and the era.

Moral development approach is an approach to moral development that gives emphasis on the cognitive aspects and development. This approach encourages students to think actively about moral issues and make moral decisions. The educators who adopt a development perspective of moral values and character attitudes believe that moral thinking individual develops in stages through a particular sequence in making a moral judgment of a lower level toward a higher level (Dolph \& Lycan, 2008).

Dewey first proposed historically cognitive development approach. He divided the children's moral development into three stages (levels) as follows: 1) Stage "premoral” or "preconventional”. In this stage a person's behavior is driven by an urge that is physical or social; 2) Phase "conventional". In this stage, a person begins to accept with little critical value, based on criteria group. 3) Phase "autonomous". In this, stage a person to act or behave in accordance with the mind and judgment to himself, not fully accept his group criteria. While Piaget made a conclusion that, the development of cognitive abilities in children affects their moral considerations.

Value educational purposes, according to the moral development of this approach are 1) to help students develop patterns of more complex moral thinking that is based on a series of higher moral values, 2) encourage learners to discuss the reasons why the choices and position their moral values, not only do share with others but also to obtain a change levels of moral values reasons learners.

This approach uses instructional methods to provide moral dilemmas discussed in small groups to obtain answers argumentative and relatively structured and do not necessarily have to come to a right or wrong answer. Through the moral argument is what allows children internalize the values of information received. However, something to keep in mind that for low-grade children of primary school age are still relatively heavy to be invited to think critically and argumentative and moral will is formed through habituation. White (2010) states that ... routines shape habits, which in turn establish attitudes.

Analysis approach places emphasis on the development of the learner's ability to think logically and scientific investigations, by analyzing the problems associated with social values. If the comparison between the value analyses approach to cognitive development approach, one important difference between the two that the analysis approach, more emphasis on the discussion of issues that includes social values. The cognitive developmental approach places emphasis on the moral dilemma they are individual. This means that the cognitive development approach and analysis approach have similar patterns of thought both are just different targets. Therefore, both have advantages and disadvantages of similar applications. Advantages, this approach is able to develop critical thinking, while weakness, this approach is relatively difficult to be applied to the age of the children of low grade.

There are two main objectives of moral education according to this approach, namely 1) helps learners to use a scientific and logical thinking skills in analyzing social issues, which relate to certain moral values; 2) helps learners to use rational thinking and analytical processes, the connection between and formulate the concept of their values.

Action Learning approaches is an approach that gives emphasis on the business of giving students the opportunity to perform moral deeds, either individually or together in a group. Superka et al. (1976) concluded that there were two main goals of education.

This approach is based on the moral. First, to provide an opportunity for students to perform moral actions, either individually or together based on their own values. Second, to encourage students to see themselves as in- 
dividual beings and social beings in association with others, who do not have complete freedom, but as citizens of a society, which must take part in a democratic process. Teaching methods used in value analysis and clarification approach is used in the value of this approach. Other methods used are also certain projects to be done in school or in the community, and practice skills in the organization or related among (Superka et al., 1976).

Values clarification approach is an approach to instructional which gives emphasis on the business of helping learners to assess their own feelings and actions, to increase their awareness of their own values. The purpose of value education according to this approach isto help learners to be able to 1) be aware of and identify their own values and the values of others; 2) communicate openly and honestly with others, dealing with its own values; 3 ) using jointly the ability to think rationally and emotional awareness, to understand the feelings, values, and behavior of their own (Lipe, 2010). In accordance with its objectives, this approach will allow the child to analyze the truth-values he had, to be honest with yourself and others and able to think rationally and improving emotional awareness.

This approach contains two main objectives: 1) provide an opportunity for learners to perform moral actions, either individually or jointly, based on their own values; 2 ) encourage students to see themselves as individual beings and social beings in association with others, who do not have complete freedom, but as citizens of a society (Lipe, 2010: p. 2). In addition to applying instructional methods applied in the value analysis approach and values clarification, this approach also, implement specific projects at school or in the community, and practice skills in the organization or in connection among (Huitt, 2004).

This approach will be able to increase the awareness, willingness to participate in the social life of the community, but not all the values of social studies instructional materials can be directly applied. As we know, that each of these approaches has advantages and disadvantages of each. By thus be necessary to develop an approach that contains all the goodness or the integration of the principles of the six theories. Principles of instructional or educational value, attitude and character as follows: 1) does not ignore the rights of the child learners to choose their own value (not indoctrinated); 2) emphasize the process can find the values of their own, according to the place and time; 3 ) encourage learners to think active, rational, analytical and argumentative in analyzing and making moral decisions; and 4) through moral argumentative, awareness of logical/rational, scientific and moral habituation acts (individual or group) students will internalize the values received.

Based on these principles can be rationally accepted that the value of instructional approach, attitude and character of the applied science by integrating a whole repertoire of these theories (character, attitude and values with an integrated instructional approach scientific values) would be the most appropriate approach in the implementation of education values, attitudes and characters in Indonesia. This approach will enable the fulfillment of the basic capital of the individual in the instructional process both in attitude, knowledge and skills in addition to meet the growing efforts of the noble values of Indonesian culture and philosophy of Pancasila.

Based on the principles of instructional values, attitudes and character, the team of researchers worked to develop instructional approaches values, attitudes and character-based social studies curriculum material content 2013 for elementary schools students.

\section{Research Methods}

This study was designed to 1) identify the weaknesses of the instructional model attitude and character in the 2013 curriculum at elementary schools, 2) develop a conceptual model of instructional attitude and character that is able to instill the values and attitudes of characters contained in the content junior high social studies as a refinement of the model of instructional achievement and attitude of the characters in the curriculum of 2013. After a) carried out research in the form of a forum group discussion (FGD) with teachers about the weaknesses of social science instructional model attitude and character in the curriculum of 2013 and b) found tentative models of instructional attitude and character, then the model is tested by experts constructive theoretical and empirical values education in the field.

This research is a qualitative descriptive study. Therefore, this study did not use but population utilizing certain social situations (place, actors and activities) that interact synergistically (Sugiyono, 2008). This is due to the research of this kind is not to generalize the results to the population but to transfer the results of these studies to other places on the social situation which has similarities to the social situation in the cases studied (Sugiyono, 2008). The social situation is in the form of elementary schools education institutions, people (prinsiples, teachers and students) and interactive activities. With respect to the type of research that is applied then the 
sample was drawn purposively, i.e. data sources retrieval techniques with consideration criteria are practitioners of curriculum in 2013, especially social studies teacher and the administrator of elementary school education (principal). Data were collected from 3 (three) elementary schools through focus group discussions, observation and interviews. There were 30 (thirty) teachers and 3 (three) principals who participated in the Forum group discussion, and also 15 students indepth interviewed. Data collected were analyzed through descriptive qualitative and argumentative.

\section{Results and Discussion}

Based on the results of research conducted through interviews and focus group discussions with teachers and social studies in junior secondary education administrator obtained eight findings as follows.

1) The process of implementation of instructional social science subjects in class implemented according to the guidelines contained in the book of teachers.

2) it is expected that the teacher before making the instructional process in the classroom seeing core competencies, basic competencies, instructional objective social science subjects, studying the subject matter of social science, and instructional approaches and measures of social science instructional activities, which are in teacher book.

3) the competency includes four competencies are competencies associated with a) the vertical relationship-spiritual, b) horizontal relationship -sosial and nature, c) the development of knowledge and d) the development of skills. Competence a) and b) referred to as the competence of attitude. The contents of the competence of social science subjects elementary schools level is expressed as follows: respect and appreciate the teachings of their religion (core competencies-1); respect and appreciate the honest behavior, discipline, tang-responsibility, caring (tolerance, mutual aid), polite, confident, in interacting effectively with the social and natural environment within reach of the association and its existence (core competencies-2); Understanding knowledge (factual, conceptual, and procedural) based on curiosity about science, technology, arts, culture and events related to the phenomenon of the visible (core competencies-3); and trying, processing, and present in the realm of concrete (using, parse, compose, modify, and create) and the realm of the abstract (writing, reading, counting, drawing, and making up) in accordance with the learned in school and other similar sources in the corner view / theory (core competencies-4).

4) Attitude competency is key competencies should be achieved in the study subjects.

5) Instructionalof social science subjects should be presented by using the scientific method approach, and using the model recommended in Curriculum 2013, the discovery-inquiry-based instructional, problem-based instructional, and project-based instructional. Instructional to use the scientific method is aninstructional approach designed so that learners actively construct concepts, laws, or principles through the stages observe, ask, gather information, associate and communicate.

6) In general, instructional to use a scientific approach carried out through the following steps. a) Learners conduct observations of a phenomenon such as image/video, surrounding environment to identify the things that we want to know from observation. b) Students formulate questions based on things they want to know the students at the time of observation. c) Collect data or information with a variety of techniques, such as reading Lerners books, search the internet, interviews with speakers or making observations in the field. d) Analyze the data or information obtained from various sources to answer the questions that have been formulated to obtain a conclusion on answers to questions that have been formulated. e) Communicate conclusions by presenting it to the class, stick to a conclusion on the classroom wall or place that has been provided as a means of learners.

Broadly speaking, the steps in the instructional of social science subjects included three major activities, namely: Introduction Activity, Core, and Closing. Here is an example of the instructional activities of social science subjects that use the scientific method to the sub-theme: "The quality of Indonesian population and the national movement”.

Preliminary activities: a) Learners with the teachers greet and pray. b) Learners with the teachers condition/ prepare the class. c) The teacher gives motivation: ask for material that has been studied in previous meetings. d) Learners receive information topics and instructional objectives of the teacher. e) The students were divided into several groups, each group consisting of 4 - 5 people.

Core activities, consisting of activity: a) Observing, namely: i) Learners are asked to observe the image 26 dioramas Youth Pledge. ii) Based on observations diorama image Youth Congress, students were asked to dis- 
cuss in groups and write down the things you want to know from observation. Example: What is the Youth Pledge, why should there oath youth, how the meaning of the oath of youth, and so on. iii) Learners are encouraged to select whether the things they want to know is in conformity with the purpose of instructional, if not, learners are asked to fix. iv) If the things they want to know not all include instructional objectives, then the teacher can add things that are related to the instructional objectives. b) asking, namely i) Learners are required to discuss in groups to formulate questions based on things they want to know from the observation map of the distribution of agricultural products in Indonesia. Questions directed to the substantive matters related to the instructional objectives. Example: why emerging Indonesian national movement? What are factors underlying the Indonesian national movement? How do the Indonesian national movements take place? Why appear Youth Pledge? How is the significance of the oath of youth for Indonesian independence movement? ii) One of the representative groups of students were asked to write the formulation of questions on the board. iii) Teacher requres students to discuss with the group to answer the questions according to what is known. c) Collecting Data/Information: teacher asked students to collect information/data to answer questions formulated from a variety of sources, such as reading Learners books, searching the internet or reading a book in the library. d) Associate/reasoning, namely i) learners are required to process and analyze the data or information that has been gathered from various sources to answer questions that have been formulated (complete provisional answers that have been formulated in the group). ii) Students are asked to discuss in groups to draw conclusions from the answers to the questions that have been formulated. e) Communicate, namely: i) Students in the group was asked to present the results of the conclusion of the answers to questions that have been formulated. ii) The other group was asked to give a response to the presentation of the results of the group conclusions. iii) Learners with the teachers take the conclusion in answer to the question.

Closing activities: a) Learners are asked to reflect on the instructional process associated with the mastery of materials, approaches and instructional model used. b) Learners are given the message about values and morals. c) Learners are given the task to enhance the results of the report group discussion about the answers to questions that have been formulated to be collected to teachers. d) Learners are given the task to read materialinstructional in the next sub-themes.

7) Based on the experience of implementing the curriculum in 2013, when the FGD is done, the social studies teacher said that in instructional activities in the book is directed only teacher asks students to move to explore, find and develop the concept of knowledge and practice skills to communicate the concept of knowledge that is found. While the execution of judgments, teachers were asked to rate all aspects of instructional outcomes, the attitude of spiritual, social, knowledge and skills. Elementary school teachers agree that the implementation of a scientific approach has impact on the student's social attitude growth of responsibility and cooperation. However, the attitude of responsibility and cooperation to grow in self-learners is only responsibility and cooperation in exploring and preparing knowledge, not an attitude of responsibility and cooperation in their entirety as social beings. Whereas the core competencies expected attitude is a) appreciate and live the teachings of their religion; b) respect and appreciate the honest behavior, discipline, responsibility, caring (tolerance, mutual help), polite, confident, in interacting effectively with the social and natural environment within reach of the association and its existence. As a conclusion, they state that the expected characteristics of the scientific approach applied in the instructional process of social science subjects will only be able to nurture and inculcate values or scientific attitude, not able to instill an attitude in full as expected in the core competencies.

8) Based on the experience delivered by the teacher when the FGD, it was found that there is a discrepancy between the contents of the instructional competencies that will be implemented to achieve the expected core competencies with competencies that would be achieved. In the core competencies, disclosed that attitude achievement (both spiritual attitudes and social attitudes) became the main target would be achieved in the instructional process, while instructional activities with scientific approach only emphasizes the attainment of knowledge and skills. In the instructional activity, students are not given the opportunity to explore, understand, and reason as well as how to apply the values contained in the subjects into everyday life. Because the instructional process students are not given the opportunity to explore, understand, and make sense of the values contained in the subject matter being studied and sought how the application of values in everyday life, it can be understood that the scientific approach as a model of social studies instructional approach is not much help instill the values of the contents of social studies into self-learners. Applying scientific approach will only help the planting of values into attitudes and character of students is limited to the planting of values/scientific attitude. The attitude of responsibility, honesty and cooperation grows well only be a responsible attitude, honesty and 
cooperation in scientific situation. While the values contained in the content of other subjects are less embedded into self-learners. Other values embedded into self-learners happened accidentally or just a side effect of the activity of the instructional process that is not intentionally pursued by the teacher. This happens because in the process of implementation of the scientific approach to instructional with only familiarize learners behave scientifically in acquiring knowledge and skills. While extracting, understanding, reasoning and application of the existing value in the content is not done. Based on the premise that attitude or character only be embedded into one's self through the process of understanding, reasoning, and a sense of usefulness of the values learned. Sense of usefulness on these values make a person grow willingness to apply back repeatedly over the value he received. This repetitiveness then becomes a habit. This habit will grow the longer the energy in one's self in the situation becomes more and more there is something missing if they are not doing it. Conditions as it is called have become a character in a person. While the instructional process with the existing scientific approach in teacher book, not seen giving instructions to the teacher to guide the learners to explore, understand, reason why it is said the values correctly, it should be done, maintained in everyday life.

In connection with these findings, then in the next FGD event, FGD participants tried to draft an integrated scientific approach in the implementation of instructional social science subjects. Integrative scientific approach is meant instructional activities that not only develop a scientific attitude of learners in exploring, analyzing, organizing and communicating concepts learned knowledge, but also to explore and analyze the values contained in the lesson is being learned and how the application of the values that in everyday life at school, family and society.

In general, instructional steps with an integrated scientific approach are as follows.

1) Preliminary activities:

a) Students and teachers say hello,

b) The teacher recalls the concepts previously learned

c) The teacher presents topics and instructional objectives to be studied.

2) Core Activities:

a) Students make observations on a phenomenon that an image/video, neighborhoods to identify the things that we want to know from observation.

b) Students formulate questions based on things they want to know at the time of observation. These questions include questions related knowledge, skills, and values that want excavated from the contents of the subjects to be studied.

c) Learners collect data or information to construct the concept of knowledge, skills, values, and attitudes that can be learned from the content of the lesson material resources through a variety of techniques.

d) Learners to reason with activities 1) analyze and conclude the data or information collected to construct knowledge and develop skills; 2) explore and discuss the values contained in the subject matter rationally why the values that need to be understood, implemented, maintained, and used as a handle to behave as individuals, groups and in public life; 3) developing a joint activity is a manifestation of values is reasonably acceptable;

e) Communicate conclusions by presenting it to the class (good conclusions about the concept of knowledge, skills development as well as implementation and preservation of the values obtained in daily life.

3) Closing Activities

a) Students are required to improve the understanding of the material that has been studied through a variety of instructional resources

b) Learners are given moral messages, encouragement to apply the design activities have been made.

c) Prayer together as gratitude for the grace of God the almighty one.

4) Follow-up activities

Recalled and monitored along with the learners to the application of the values that have been studied in daily life.

Furthermore, FGD (social science teachers) applysinstructional approaches together agreed. The results showed that learners much faster growing spiritual attitudes, social attitudes (honest, discipline, tang-responsibility, caring, tolerance, cooperation), polite, confident, in interacting effectively with the social and natural environment in comparison with the application of scientific approach teacher in the book. This happens because the instructional values and attitudes or character-based integrative scientific approach, learners are deliberately invited to explore, understand, make sense of the values contained in the subject matter being studied. Digging 
experience, understand and make sense of values that exist in the content of instructional material makes learners become totally accept or logical reason why such values that need to be viewed, copied and applied in society. This awareness makes students feel happy and want to maintain those values. In other words, this awareness makes the values embedded into itself or into the attitude and character of students. This is in line with the opinion of the Kesuma, Triatna and Permana (2011) that the logic and rationality that is the important measure to produces a rich person's decisions. Someone will do and do it steady when everything done rationally acceptable. Examples of behavior can be easily accepted if anything; it has a sense of acceptance. Something, which is accepted by the mind, will develop in a person into something that is felt to be liked or disliked by her feelings. Something like will be a value that is a tendency attitude that encourages you to do and will even try to defend and fight for it. Sartono (2010) also said that the attitude contains cognition, feelings and behavior tendency to act on an object. Cognitive influence positive or negative feelings and feelings affect the tendency to act. Affective-cognitive consistency theory suggests that the affective component of the attitude of the system may be changed by first changing the cognitive component through providing new information (Miller, 2012).

Individual attitudes toward an object depends on the information obtained from an object is perceived as positive or negative. Changes in individual cognition of an object will tend to result in changes in feelings and tendencies toward an object. Thus, the rational acceptability of information is considered as a positive or negative will affect the propensity to act on that object. In other words, the acceptance of information from the subject matter in the form of the values that have been analyzed rationally why it needs to be done, what are the benefits, how to do it by the individual concerned will strengthen the tendency to act or attitude towards these values. Decisions of the object to do something or not, maintained or not is determined by the rationality of the acceptability of an object. Decisions on the outcomes of instructional something of value to be done or not, maintained or not is determined by the rationality of acceptance into a value that has been studied as something that is rational or not. If the value that has been received because of thinking rationally, perceived goodness and usefulness in life, done repeatedly over time it will become an ingrained habit. Ingrained habit has become a cultural meaning in life or has become a character in his life. Thus the development of character through the instructional process will be formed, when the instructional process is done through an activity that makes learners become aware of what the nature of the study, what the values contained therein, where the values need to be emulated, why is the value that needs to be replicated and maintained, practiced in daily life repeatedly.

White (2010) states that ... routines shape habits, which in turn establish attitudes. While Arwani (2008) asserts that something good is seen to be done and done repeatedly will become entrenched customs and or internalized in him, so that they feel reluctant and felt there was something missing when abandon, and feel the need to preserve and maintain the value. That is something that is obtained from the study of an individual will be a character in itself, if practiced in daily life continuously.

\section{Conclusions}

The results of this study showed that 1 ) scientific instructional approach was only able to develop scientific attitudes of students, while sorts of other attitudes were very less embedded into the self; 2) The application of the integrated scientific instructional approach was able to instill the values of attitudes and characters contained in the content of social studies to the student intact.

There are some limitations of this study. Firstly, the area of this study only consists of three schools, and secondly, there were only thirty teachers and three principals participated in as subjects of the study, and only 15 students were depth interviewed. In this case, the result of this study might be lack of credibility and transferability. Therefore, I am expecting other researchers to continue this study with more schools and more subjects of research and deeper interviews and triangulation in order to have results of research, which are more credible, transferable, dependable and confirmable.

\section{Acknowledgements}

Firstly, we would like to acknowledge the Directorate of Higher Education Ministry of Education and Culture Republic of Indonesia, which provided fund for this research project. Secondly, we would like to thank all of the heads of the research and social service Board Bengkulu University who coordinated and facilitated administration of this research project. Lastly, we would like to thank the heads of junior elementary school I, Bengkulu 
Municipality and the heads of junior elementary school I, Bengkulu Centre County, teachers, support staff, and students who helped us develop and complete this project through their participation and cooperation.

\section{References}

Arthur, J. (2005). The Re-Emergence of Character Education in British Education Policy. British Journal of Educational Studies, 53, 239-254. http://dx.doi.org/10.1111/j.1467-8527.2005.00293.x

Arwani, M. (2008). MemaknaiTradisiBerkatMuludan di KranjinPurworejo. In I. Abdullah, I. Mujib, \& M. I. Ahnaf (Eds.), Agama dan Kearifan Lokal dalam Tantangan Global (pp.187-211).Yogyakarta: Sekolah Pascasarjana, Gajah Mada University.

Dolph, K., \& Lycan, A. (2008). MoralReasoning: A Necessary Standard of Instructional in Today’s Classroom. Journal of Cross-Disciplinary Perspectives in Education, 1, 13-19.

Huitt, W. (2004). Moral and Character Development. Educational Psychology Interactive. Valdosta, GA: Valdosta State University. http://www.edpsycinteractive.org/topics/ affect/ values.html

Kementerian Pendidikan dan Kebudayaan Republik Indonesia (2013). Materi Pelatihan Guru Implementasi Kurikulum 2013 SD/MI. Jakarta: Kementerian Pendidikan dan Kebudayaan.

Kementerian Pendidikan dan Kebudayaan (2014). Buku Guru Ilmu Pengetahuan Sosial Kelas VIIIL. Jakarta: Kementerian Pendidikan dan Kebudayaan.

Kesuma, D., Triatna, C., \& dan Permana, J. (2011). Pendidikan Karakter: Kajian Teori dan Praktik di Sekolah. Bandung: PT Remaja Rosdakarya.

Koran Sindo Newspaper. 28 January 2014.

Lipe, D. (2010). A Critical Analysis of Values Clarification. Montgomery, USA: Apologetic Press, Inc.

Miller, M. (2012). Teaching and Instructional in Affective Domain-Emerging Perspective. http://projects.coe.edu/epltt/index.php?title=TeachingandLearn

Sartono, S. W. (2010). Pengantar Psikologi Umum, Jakarta: Rajawali Pers.

Sugiyono (2008). Metode Penelitian Pendidikan: Pendekatan Kuantitatif, Kualitatif, dan R \& D. Bandung: Alfabeta.

Superka, D., Ahrens, C., \& Hedstrom, J. (1976). Values Education Sourcebook. Boulder, CO: Social Science Education Consortium, Inc.

Wahab, A. A. \& dan Sapriya (2011). Teori dan Landasan Pendidikan Kewarganegaraan. Bandung: Alfabeta.

White, R. (2010). Building Schools of Character: The Development, Implementation, and Evaluation of School-Based Character Education Programme Designed to Promote Cooperative Instructional and Reduce Anti-Social Behavior. Ph.D Thesis, Durham: Durham University. http://etheses.dur.ac.uk/180/ 